\title{
食鷄の生産自動化システム* \\ Food Robotics Deboning Process of Chicken
}

\section{兒玉龍二** \\ Ryuji KODAMA}

Key words food robotics, deboning process of chicken

\section{1. は じめに}

普段食べている鶏・豚・牛の肉は, 農場で飼育し, その 後に処理工場で商品の肉に加工処理される。 スーパーマー ケット等で精肉や惣菜等の加工商品として販売され，一般 家庭のテーブルへと並ぶ。農場で飼育されている様子は, テレビ番組等で見る機会が多々あるが，それらの家畜を屠 殺し，食肉として加工する様子を見ることは少ない．

今回, 食鶏処理工場内で, 商品としての肉の形態へ加工 する食鵎生産自動化システムについて紹介する。

\section{2. 食鷄の生産自動化システム開発の経緯}

大量生産されている鵎のことをブロイラーと呼んでいる が, 一般的に食心゙られている鶏肉は, 効率的に鶏肉を供給 する手段としてアメリカよりブロイラー生産方式が導入さ れ現在に至っている。食鶏生産の自動化への取り組みは, 欧米を中心に 1950 年代から行われている. 機械化を開始 した当初は鷄を固定する簡単な治具や, 内臟を取り出す器 具に始まり, 効率を高める中で多くの自動処理機が開発さ れ実用化されている.

鶏肉の処理工程は, 「屠畜」工程から内臟を取り出す 「中抜き」までの工程と, それ以降の骨と肉を分離する解 体工程とに分け, 最後に計量, パッキング, 箱詰を経て出 荷となる.

「中抜き」までの工程は, 欧米の食鷄処理機メーカーに より自動化が行われているが, 解体工程については, 骨か ら肉を分離する食肉加工そのものであり, 人の器用さに頼 る必要もあり, 自動化がなかなか進まず, 今でも作業内容 によっては人海戦術で生産が行われている。しかし, これ らの作業は, 包丁を使い危険が伴い, コンベアに向かって の長時間の立ち仕事という過酷な労働であるため, 作業者 の定着率が低く, 若い人達から好まれない職場となってい る. また, 現在従事している作業者の高齢化と団塊世代の

*原稿受付 平成 27 年 6 月 17 日

**(株) 前川製作所佐久工場 (長野県佐久市長土呂 774)
大量退職等の問題を考えると, 労働力の確保は今後さらに 困難になってくるものと考えられる。これらの問題を克服 し, 価格面・品質面で競争力を付けるために, 食鷄処理作 業に抢いて自動化, 省力化機械を中心とした, 安全で衛生 的で, かつ高品質な生産設備・生産システムの構築が食鶏 処理業界上り強く求められている。筆者らは, 食䳕産業の 生産性の向上, ならびに安定化を目的とした生産自動化シ ステムの開発に取り組んでいる.

\section{3. 食鶏の解体の説明}

食鷄の解体工程は, 大ばらし工程, 胸肉脱骨工程, 腿肉 脱骨工程の 3 工程に分かれ構成されている。筆者らは, こ の 3 工程に执いて, 1995 年に開発を開始し, 現在に至る までの間, 全自動化を目指し, 自動化処理システムの開発 を行っている.

食鶏を機械で自動処理する場合の問題点として, 食鶏の 大きさ・形状・硬さが 1 羽ごとに異なっているため, その 個体差に対していかにフレキシブルに機械が追従して適切 な処理を行えるかが課題である，筆者らが食鶏の処理装置 を開発する以前の食鶏処理装置は, 鶏の大きさに対しての フレキシブル性がなく, 大きい鷄, 小さい鷄ともに同じ設 定位置で加工が行われていた。 これらの装置の場合, 装置 の設定と鵎のサイズがマッチしたときは, 歩留りと品質の よい脱骨処理が行われるが, 設定寸法から外れた鵎の場合 は, 鷄に対して強引な処理が行われるため, 歩留り・肉の 品質が不安定となっていた。筆者らは, 不定形軟弱体にフ レキシブルに対応できる機能を作り出すことを課題として 開発に取り組んだ。

工業系の加工機械は, 対象ワークが, 大きさ・形状が定 まり, ある程度の硬さがあり, 掴んでも変形しない物を, 決められた寸法に装置を設定し, 決められた動作をするこ とで安定した加工処理が行える. しかし, 不定形軟弱体の 場合, 大きさ・形状・硬さが一羽ずつ異なる鷄肉に対し て,フレキシブルに処理を行えるようにするため, 鷄肉に 直接接触する部分にバネ等による逃げ機構をもたせて, ば らつきに対する柔軟性をもたせた。 


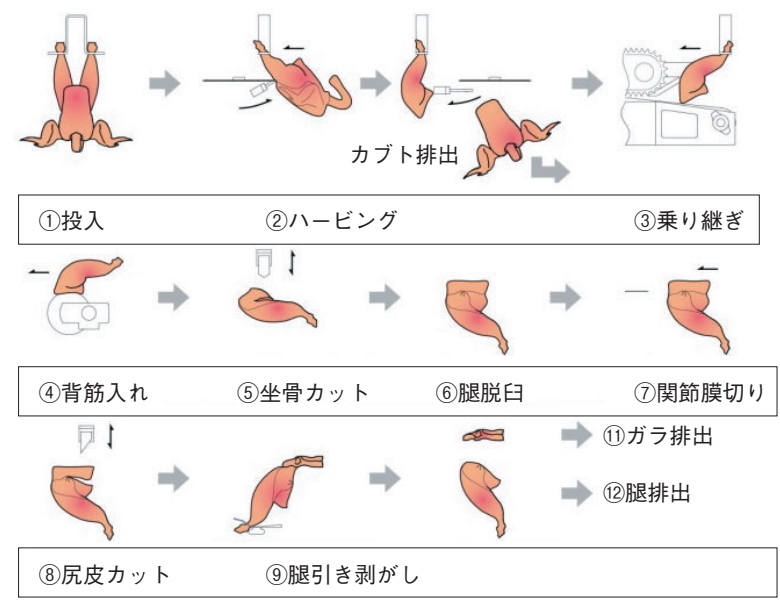

図 1 大ばらし工程

もうひとつ重要な対応策として, 鶏を 1 羽ずつ計測する ことにより大きさのばらつきに装置側が追従して動き, 適 切な処理を行うことである。計測には，重量測定，接触・ 非接触でのセンサによる長さを測定, 画像認識による計測 の 3 種類を採用し，実用化している.

\section{1 大ばらし工程}

内臓を取り出す「中抜き」後，中抜き屠体は，大ばらし 処理を行う．大ばらしとは，中抜き屠体のフロントハーフ (上半身) と腰骨付き下半身とに分割し, 腰骨付き下半身 からからレッグ（骨付き腿肉）を剥ぎ取る作業である.

一般的に大ばらし装置と呼ばれており, 欧米の食鶏処理 機メーカーも商品化して扔り全世界で普及している。

大ばらし装置は，上半身と下半身に分割するハービング 機構, 分離された腰骨付き下半身を, 骨付き腿肉と腰骨に 分離するレッグプロセス機構とで構成されている。

図 1 に筆者らが開発した, 大ばらし装置の処理工程を 示す.

(1)中抜き屠体を大ばらし装置へ投入する。(2)ハービング 機構では, 両足首を固定し, 吊った状態になった中抜き屠 体のフロントハーフ剣状軟骨を位置決めし，フロントハー フとレッグ両方を傷付けずに，関節の中心を回転する丸刃 で切断する. 次に(3)レッグプロセス機構へ, 乗継ぎさせ る，大きさ・形状の異なる坐骨部を坐骨強制ガイドに押し 付けることにより，坐骨の形状を矯正し，刃物が坐骨全面 に接して確実に肉を切ることと, 腰骨の腸骨から坐骨先端 までの長さを, 光電センサを使用して測定し，大きさのば らつきに対して正確な処理が行えることを特徴としてい る. (4)背筋入れで背中の中心部の皮に切れ込みを入れる. (5)座骨部の切り込みで坐骨と肉を切り離す. (6)腿脱臼で股 関節を脱臼させる。(7)関節膜切で股関節部と大腿骨をつな いでいる腱を切断する。(8)尻皮カットで坐骨と皮を切り離 す．99腿の引き剥がしで腰骨から腿を完全に引き離す，以 上の工程を経て，人手と同等の腿肉歩留まりを保ちながら 自動での大ばらしを行うことが可能となっている.

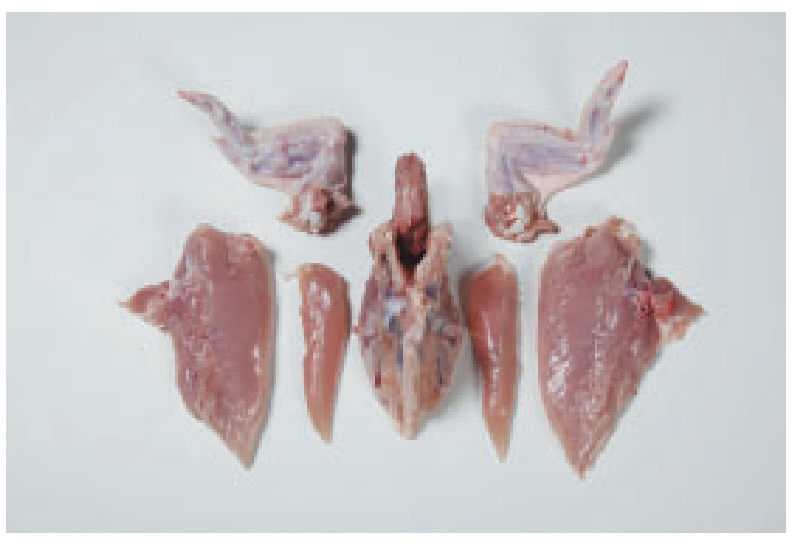

図 2 胸肉脱骨処理された鷄の状態

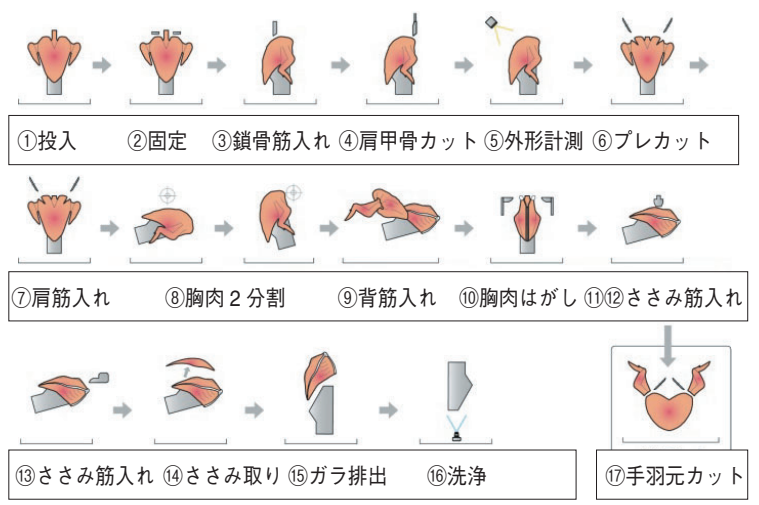

図 3 胸肉脱骨工程

\section{2 胸肉脱骨工程}

胸肉脱骨工程とは，大ばらし工程で分割されたフロント ハーフから胸肉・ささみ・手羽元・手羽先の部位を分割す る作業である。図 2 に示す。

この胸肉脱骨工程の加工処理機は, 一般的に, 胸肉脱骨 機と呼ばれている，筆者ら以外の欧米の食䳕処理機メーカ 一も商品開発し, 全世界でそれぞれの国や食彩処理会社の 商品形態，機械化する上での目的に合わせ，使い分けられ ている.

図 3 は, 胸肉の脱骨工程を示す. 1)フロントハーフを 胸肉脱骨機のコーンと呼ばれている治具へ投入する。(2)フ ロントハーフはコーンに固定される. (3)鎖骨を傷付けずに 周りに覆った肉へ切れ込みを入れる。 (4)背中側の肩甲骨と 肉を切り離す. (5)フロントハーフを画像処理カメラで撮像 し，外形形状を認識する。 (6)7肩と手羽元をつなぐ関節の 腱を切断する. (8)胸肉側の中心部に切れ込みを入れる. (9) 背中側の中心部に切れ込みを入れる. (10)手羽元を掴み, 胸 骨から胸肉を引き剥がす。117引き剥がした胸肉から手羽元 を切断する。(11)1213开サミに覆いかぶさっている膜を 3 方 向から切り開く. (14)ササミを掴み胸骨からササミを引き剥 がす，以上が自動での胸肉脱骨工程である。

胸肉を脱骨する際, 肩の関節部の肉と腱を切断し, フロ ントハーフから胸肉を剥ぎ取る。この作業が, 胸肉脱骨工 


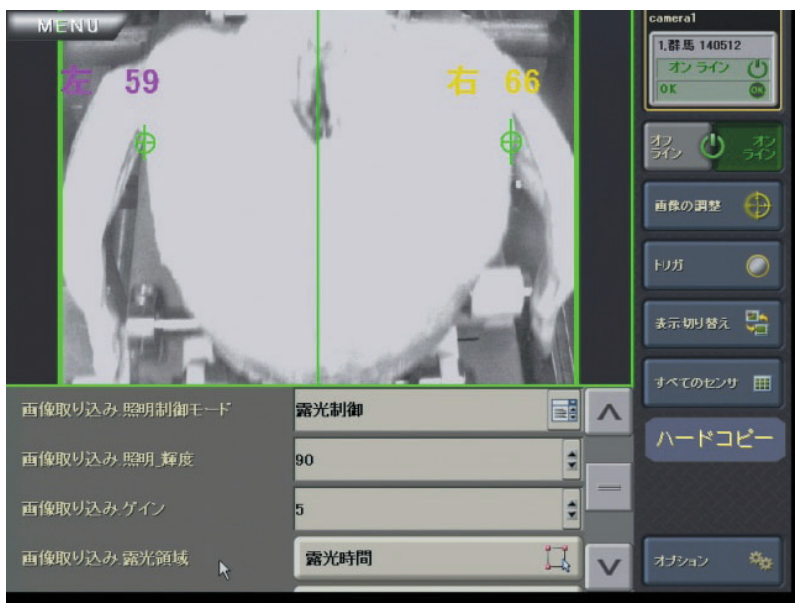

図 4 フロントハーフ幅寸法計測撮像写真

程で最も重要で, かつ, 熟練を要する部分である. 肩の関 節の腱は, 正確に切断しなければ, 胸肉を引き剥がす際 に，フロントハーフの骨を骨折させてしまう。骨が骨折す ると完全に胸肉を引き剥がすことができなくなり，手直し 作業として，より手間の掛る作業となってしまう。また， 胸肉に骨が混入する場合もあり，異物となるため残骨取り の作業を行わなければならなくなる。

人手での作業の場合, 熟練された職人技で肩関節部の腱 を適切な深さで正確に切断し脱骨を行う. しかし, この作 業を機械で行うとなると，鵎の大きさがばらついているた め，肩関節の腱を毎回正確に切断することは，高難度なも のとなる.

欧米で商品開発された胸肉の脱骨機は, 肩関節腱の切断 自動化を断念し, その作業だけは, 人手作業で行う, マンマ シンシステムとして食䳕処理場へ導入している. また, 腱を 切断する場合, 深さがまちまちとなり, 歩留りや胸肉への傷 つきが発生し，安定した生産を行うことが難しくなる。

筆者らが, 開発した胸肉脱骨機では, フロントハーフの 外形を画像処理装置のカメラで撮像し, フロントハーフの 横幅寸法を認識する。図 4 に示す。そのデー夕をもとに, 鷄の肩関節中心位置を想定し, 丸刃の刃先が毎回肩関節中 心へ来るようにサーボモータを使い位置制御を行い, 肩関 節腱の切断を自動化している.

\section{3 腿肉脱骨工程}

鷄の腿モモ肉脱骨工程は，骨付き腿肉から，骨と肉を完 全に分離する作業を行う，図 5 に示す。筆者らは，世界 で初めて腿肉脱骨の全自動化に成功した。腿肉脱骨機の開 発にあたっては，作業工程を詳細に検討し，かつ設計担当 者が自ら加工の実習を受け, 腿肉の特性を知って加工の) ウハウを把握し，設計に反映させた。タクトタイムは 3.6 秒で，1 時間当たり最大で 1000 本の処理能力がある。腿 肉脱骨機の各工程は, 同心円上に配置され, 腿が 10 工程 を一回りすると腿肉と骨の分離が完了する。回転駆動する 丸刃による腿肉の肉や腱の切断と骨から肉の引き剥がしを 繰り返すことで脱骨を行っている，全行程は図 6 に示す.

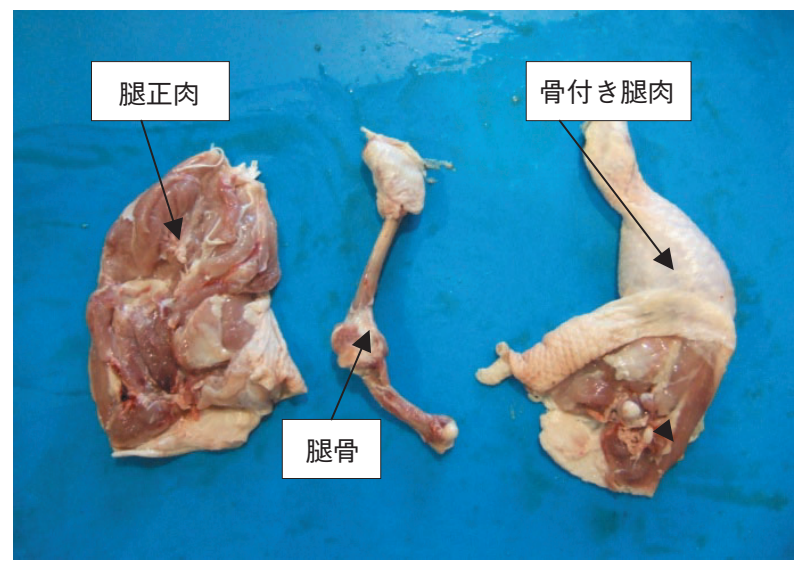

図 5 腿肉脱骨前と後の状態

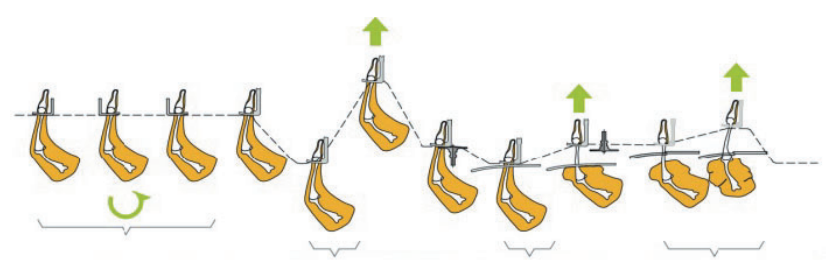

(1)

(2)

(3) (4)

(5)

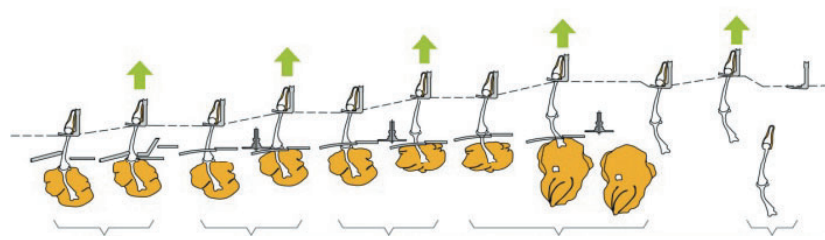

(6) 7

(8)

(9)

(10)

図 6 胸肉脱骨工程

(1)腿肉を脱骨機のクランパと呼ぶ治具へ投入する。(2)足首 部から大腿部の骨に沿って，ナイフで切れ目を入れる。(3) 足首部を回転駆動する丸刃で皮と腱を切断する。(4)(5)足首 部から脛部, 膝部の肉引き剥がす。 (6)膝関節中心位置の計 測をし，以降の工程での位置決めの基準とする。(7)899膝 関節部から膝関節㿼骨部, 大腿骨部までの肉と腱の切断 と, 肉の引き剥がしを行う。110大腿骨付け根部の肉と腱を 切断し, 骨と肉を完全に分離する. 以上が自動での腿肉脱 骨工程である。

腿肉脱骨をフレキシブルに行う機能の一つである, ミー トセパレータ部について説明する。ミートセパレータは, 2 枚の開閉する板により構成されており, 骨を挟みこみ, 肉を押さえながら, クランパを引き上げて肉を剥がしてゆ く．引き剥がす骨の径は足首部で約 $10 \mathrm{~mm}$, 膝関節部で は約 $25 \mathrm{~mm}$ と各部分で異なっている。ミートセパレータ は各工程での骨の断面形状に合った切り欠きをもち（合計 5 種類), さらにバネで逃げる機構により, 骨の径に追従 しながら歩留まりよく肉を剥がすことが可能である。図 7 は，肉引き剥がし部の機構を示す。肉の引き剥がしの際， 


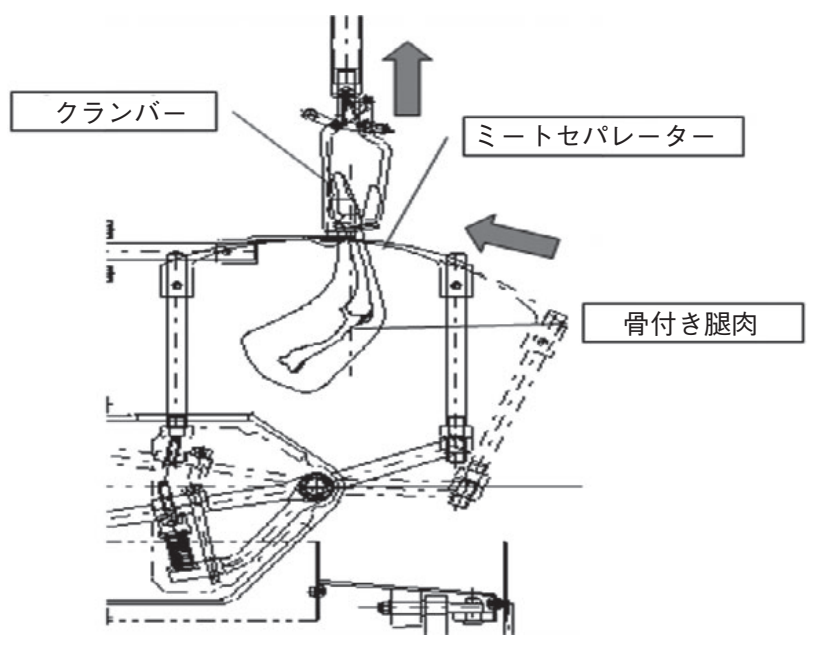

図 7 肉引き剥がし部の機構

膝関節部に肉と骨を締結している強い腱があり, 腱を切断 しなければ引き剥がしができない。ただし，この腱にも切 るべき位置があり，許容範囲は $5 \mathrm{~mm}$ ほどの幅しかない. この許容範囲内で筋を切断しなければ，歩留まりの低下や 肉の損傷が起こる. 腿肉の足首から膝関節までの長さは, 鶏の大きさのバラツキにより最大で約 $40 \mathrm{~mm}$ の差があり, 安定した腱の切断を行うためには鵎の個体差に合わせ, 切 断位置を変える必要がある。

筆者らが開発した腿肉脱骨機では膝関節の腱を的確に切 断するために，膝関節位置を 1 本ごとに計測している，計 測データにもとづき，クランパの引き上げ量を制御し，サ ーボモータで位置決めを行い, 鶏の個体差に応じた最適な 筋の切断を可能としている。膝関節の計測は, 関節部の凹 凸をならい機構により読みとっている。板状の測定板を膝 関節より少し上部の骨に当て, 腿肉を引き上げる。測定板 は距離センサと直結し，骨の形状にならい測定板の動きを 計測する構造となっており，腿肉を引き上げると，膝関節 上部の骨のふくらみから，関節中心の谷の部分までをなら ってゆく，距離センサは計測板が読みとった骨の凹凸を数 值データに変換し, マイナス偏差が最大值となる位置を関 節の中心と判断し, 計測する仕組みとなっている. 計測部 の構造を図 8 に示す。計測により，膝関節部の腱の適切 位置を毎回切断することが可能になり，腿肉脱骨機は，人 手作業同等の品質と歩留りを確保することが可能になって いる.

膝関節部の切断後, ミートセパレータにより大腿部の肉 を引き剥がし, 最終的に大腿骨付け根部と肉とを締結して いる腱を切断し，骨と肉は，完全に分離される。骨の太さ のばらつきにフレキシブルに対応できるバネによる逃げ機 構をもったミートセパレータと, 骨の長さのばらつきに対 し, 膝関節中心位置を計測し, 適切位置の切断を行うこの 二つの機構の組み合わせと, 脱骨処理をする鷄の骨付き腿

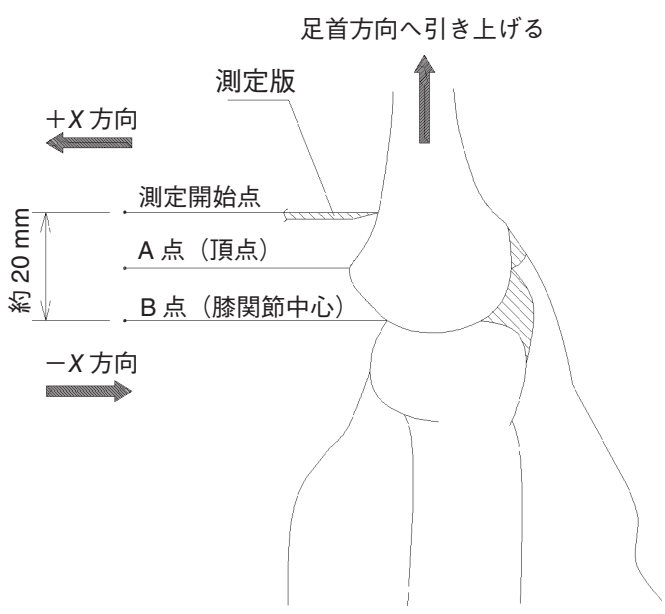

図 8 膝関節中心の計測

肉の特性と脱骨方を把握したことで全自動腿肉脱骨機は, 実用化することができた。

\section{4. おわりに}

鷂にかぎらず，牛豚羊の食肉，魚介類といった水産物の 自動化は, 自然界の物を処理の対象ワークとしており, 大 きさと形状のばらつきに対し，いかにフレキシブルに対応 するかが, 実用化の重要課題となる。 エックス線画認識技 術とロボット技術を組み合わせた食肉処理ロボットの開発 も並行して進めており，すでに実用化され始めている。こ れらの自動化を推進することは，一次産業の活性化におい て将来的に必要とされる開発事業と捉えている。世界の人 口が増加を続けているが, 一次産業に従事する作業者の技 能の低下と作業人員減少に伴う食糧の不足が今後の世界で 懸念されているが, 人類にとって食糧問題は, 避けては通 れない課題である。 日本のロボット技術展開の一つの方向 として, 食品食肉処理の機械化・ロボット化が, 世界の食 糧事情に今後大きく貢献されることを期待したい.

\section{参 考 文 献}

1）副島孝一：食品工場における低温・無人化システム一食鳥処理 施設の例一，食品機械装置，6 (1998) 52

2) 万本信三, 江龍晃 : 食肉・水産加工機械の設計, 設計工学（日 本設計工学会誌) 35,1 (2000) 2 .

3）兒玉龍二：食品食肉自動加工機械 全自動チキン腿肉脱骨ロボ ット「トリダス」, 日本機械学会誌, 116（2013）146.

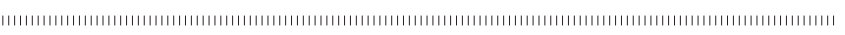

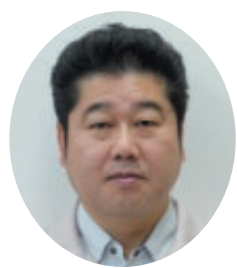
兒玉龍二

1986 年東海大学工学部生产機械工学科卒業. 現 在, (株) 前川製作所取締役. 食品食肉加工ロボ ット開発製造に従事. 